\title{
Community-based teacher professional development in remote areas in Indonesia
}

\author{
Ignatius Harjanto, Anita Lie, Diah Wihardini, Laura Pryor \& Mark Wilson
}

To cite this article: Ignatius Harjanto, Anita Lie, Diah Wihardini, Laura Pryor \& Mark Wilson (2017):

Community-based teacher professional development in remote areas in Indonesia, Journal of Education for Teaching, DOI: 10.1080/02607476.2017.1415515

To link to this article: https://doi.org/10.1080/02607476.2017.1415515

\section{Published online: 13 Dec 2017.}

Submit your article to this journal \lceil

View related articles

View Crossmark data $\circlearrowright$ 


\title{
Community-based teacher professional development in remote areas in Indonesia
}

\author{
Ignatius Harjanto ${ }^{\text {(D) }}$, Anita Lie ${ }^{\mathrm{a}}$ (D) Diah Wihardinib,c (D), Laura Pryorc (iD and \\ Mark Wilsonc (D)
}

\begin{abstract}
${ }^{a}$ English Education Department, Widya Mandala Catholic University, Surabaya, Indonesia; ${ }^{b}$ Mathematics Department, School of Computer Science, Bina Nusantara University, Jakarta, Indonesia; 'Berkeley Evaluation and Assessment Research (BEAR) Centre, University of California, Berkeley, CA, USA
\end{abstract}

\begin{abstract}
The Indonesian government has been struggling to improve the quality of teachers in its public and private schools. Several programmes of teacher education and teacher certification have been designed to enhance teacher quality. However, the programmes do not yet develop effective teachers. Supporting the government programmes, the Tanoto Foundation has facilitated teacher professional development programme since 2010, specifically in elementary schools in the provinces of Riau, Jambi, and North Sumatra. This paper first describes how the Tanoto Foundation has designed and implemented its teacher quality improvement programme for in-service teachers in remote schools in Indonesia and then uses this context to examine to what extent teachers benefited from these programmes. Reported findings broaden our understanding of how teachers can improve their quality via privately sponsored programmes.
\end{abstract}

\section{ARTICLE HISTORY}

Received 1 July 2016

Accepted 16 November 2017

\section{KEYWORDS}

Teacher professional development; programme evaluation; teacher learning; Indonesia

\section{Introduction}

The Indonesian government realises that teacher quality is pivotal. For more than a decade, the Indonesian government has paid serious attention to the quality of its teachers by instituting education policy reforms through Teacher and Lecturer Law No. 14 passed in 2005, which was aimed at enhancing teacher quality and professionalism through teacher education and professional development. All teachers must meet the minimum standards of a four-year degree and should be formally certified. All teachers take part in teacher professional development programmes and take a series of teacher assessment to earn teaching certificates. This paper focuses on the outcomes of professional development training for teachers in remote areas of Indonesia.

Research on teacher professional development programmes has gained considerable interest among researchers from many countries, including Indonesia. The point at issue is what it is to be an effective teacher. Reviewing previous studies, Darling-Hammond (2000b) found that student achievement is determined more by teacher effectiveness. Including in 
teacher effectiveness is preparation in both pedagogic and subject content, credentials, experience, and test scores (Rice 2003). Rass (2012) reported that induction programmes 'develop cultural competence to help the new teachers to deal successfully with the pupils and empower them in promoting multiculturalism' (141). In Indonesia, teacher professional development programmes and other forms of training have been conducted, but they are not yet considered to be effective in increasing teacher quality (Jalal et al. 2009). World Bank research results have confirmed the weakness of Indonesian teacher quality (Chang et al. 2014). Although improving teacher quality is underway through several projects designed to enhance teacher education and certification programmes in Indonesia, it will take several years before project directors will be able to provide evidence that they are developing effective teachers (Koning 2012; Chang et al. 2014).

To fill in this gap, the Tanoto Foundation (a philanthropic organisation with a mission to work with communities and partners to address the root causes of poverty through education, empowerment, and enhancement of quality of lives) has designed and implemented a school improvement programme (SIP) beginning in 2010, specifically focused on the elementary schools in the Indonesian provinces of Riau, Jambi, and North Sumatra. Most of those schools are located in remote areas, which present significant challenges for district education officers to carry out their responsibilities of providing adequate education resources and supervising their quality attainment. Through coordination and collaboration with the Ministry of Education and Culture (MoEC) at the national level, and Education Offices at the provincial and district levels, the SIP is implemented through the involvement of local communities and the establishment of sustainable models. Furthermore, the SIP consists of six components which include (i) development of schools that are safe, healthy, and environment-friendly, (ii) support for library establishment, (iii) development of model schools, (iv) support for early childhood development centres, ( $v$ ) capacity building efforts for teachers, and (vi) establishment of a professional development programme. This paper focuses on the last component and looks into the outcomes of the professional development programmes on teachers' knowledge and practices.

Although improving teacher quality is a crucial step for improving school quality, few studies have been undertaken in Indonesia to investigate how teachers engage their students in learning processes in the classrooms, particularly in remote regions. Lecturing and rote-learning seem to be the most dominant mode of teaching (Jalal et al. 2009). The teacher development programme developed by the Tanoto Foundation aims at enhancing the capacity of teachers to apply student active-learning methods as well as enhancing their best practices in teaching, referred to as Active, Innovative, Creative, Effective, and Pleasant Learning (AICEPL). In addition to receiving the education facilities and resources, each partner school sends five teachers to participate in professional development sessions on the following modules: Developing Contextual Teaching and Learning, Higher Order Thinking, Problem Solving, Cooperative Learning, Creating a Learning Environment that Motivates Students to Learn, Teaching Preparation and Practices, and Action Planning. The professional development (PD) sessions involved both teachers and principals. During the last session on Action Planning, specifically, each school (the principal and teachers) had to develop the follow-up plan from the training, and create a school improvement indicator as proof of the improvement of the school quality. 
This study focuses on how the Tanoto Foundation designed and implemented their teacher quality improvement programmes for in-service teachers in remote schools in Indonesia and discusses to what extent teachers benefited from these programmes (Tanoto Foundation 2016). The study involves 193 in-service teachers in 350 schools in the Provinces of North Sumatera, Riau and Jambi. This study investigates the extent to which the professional development trainings enable teachers to (1) enhance their knowledge of student active learning, and (2) improve their teaching practices.

\section{Research on professional development for in-service teachers}

Considering that education is one of the fundamental priorities of nation building, the Indonesian government continuously seeks to improve the quality of its teachers. The Indonesian government calls for mandatory bachelor degrees for all teachers at elementary and secondary schools. Besides formal education, teacher PD programmes are conducted by appointed teacher education institutions and/or local governments to certify the teachers. Further, all certified teachers need to engage in continuing professional development (Chang et al. 2014). Through teacher education and professional development, the Indonesian government tries to improve the Indonesian education by upgrading teachers' qualifications and skills (Koning 2012). As professionals, teachers need to engage themselves in continuous professional development. They must'be able to reflect on their own teaching (including with their peers) and improve their performance accordingly' (Chang et al. 2014, 44).

The Teacher and Lecturer Law, initiated in 2005, entrusts teacher quality reform in Indonesia to a teacher certification programme (Fahmi, Maulana, and Yusuf 2011). This certification programme aims to 'improve on the previous teaching license program' (Jalal et al. 2009, 24). In Indonesia, teacher certification is official recognition for teachers who have reached the standards endorsed by the education authorities and serves as a mark of a teacher's competence in subject-matter knowledge and teaching methodology. However, studies on the implementation of the Indonesian teacher certification programme revealed unsatisfactory results. Evans et al. (2009) found that the impact of teacher certification only resulted in increasing a teacher's living standard but did not increase either students' achievement or teachers' quality. Fahmi, Maulana, and Yusuf (2011) concludes that teacher certification has had no impact on students' achievement. Furthermore, Abbas (2013) argues that the teacher certification programme contributes little to the improvement of national education quality. Studies by the World Bank (2010) showed that teachers in Indonesia did not demonstrate significant increases in their classroom behaviour and performances even after completion of the certification programme and receiving increased salary.

Similar to the issue of teacher certification, effectiveness of professional development programmes is a salient issue. By carrying out meta-analyses of studies of teacher professional development programmes in mathematics and science in the USA, Blank and de las Alas (2009) found that 16 studies reported significant effects of teacher development on improving student achievement. Schleicher (2015) reported that teachers in Indonesia attending a teacher development programme in which the district office and the school supervisors were directly involved, felt more confident and better prepared than teachers not attending such programmes. These findings are consistent with Ebersöhn et al. (2015) 
who found that school intervention for in-service teachers in high-risk and high-need schools in South Africa motivated teachers to gain competency and optimism, demonstrate management skills, and make valuable contributions in a group. Similarly, Bai (2014) found that a school-based professional development programme in Hong Kong enabled teachers to be more confident in teaching. They benefited at a more practical level as they could immediately translate the recommended principles into their practices.

However, not all teacher development programmes are effective. Chang et al. (2014) argued that one-off seminars and in-service short courses in cascade fashion are not effective modes for development programmes in Indonesia. Czerniawski (2013) reported that teachers in England, Norway and Germany joining similar professional development programmes were dissatisfied with the quality and outcomes. Díaz-Maggioli (2004) identified 11 ineffective factors of professional development. These are: a top-down decision-making model, a 'fix-it' approach, lack of programme ownership among teachers, prescriptive ideas, one-sizefits-all techniques, fixed and untimely delivery methods, little or no follow-up, decontextualized programmes, a lack of proper evaluation, and a lack of pedagogical (child-centred) instruction.

Professional development programmes should take into consideration the practical knowledge and skills to help students achieve their learning outcomes, and thus ideally should contribute to and assist students' learning. Walter and Briggs (2012) reported that professional development was effective due to (a) concrete and classroom-based inclusion of expertise from outside the school, (b) involvement of teachers in the choice of areas to develop and to undertake activities, (c) programme collaboration of teachers with peers, (d) provision of opportunities for mentoring and coaching, (e) sustaining effort over time, and (f) effective school leadership support.

One of the most important strategies to enhance education performance in a country is to improve its teacher quality. Teacher quality is a pivotal policy issue in education reform in any country. Three years learning with a high-performing teacher rather than a low-performing teacher, can make a 53\% difference between two students who started at the same achievement level (Barber and Mourshed 2007; Chetty, Friedman, and Rockoff 2011).Research in the USA (Darling-Hammond 2000a; Darling-Hammond and Berry 2006), India (Kingdon 2006), Pakistan (Tayyaba 2012), and China (Wang and Lu 2012) suggests that teacher quality can strongly affect student achievements. Furthermore, Archibald et al. (2011) state that teacher quality matters because teachers have a more significant influence on student achievement than any other school factor.

Issues of teacher quality can be responded to by developing compelling programmes of teacher education and professional development for teachers in several countries. For example, Shi and Englert (2010) argue that the development of Chinese teacher education should be regarded as a key strategic measure in developing education. Further, they expect that, between 2015 and 2020, teachers of primary and secondary schools in China should earn a Master of Arts in Education in order to advance their profession. In Finland, the professionalism of teaching has been supported by an academic university education since 1970 (Tirri 2014). In Canada, teacher education bridges theory and practice involving key stakeholders such as administrators and in-service teachers in schools and teacher educators in universities (Howe 2014). 


\section{Methods}

This study represents an explanatory mixed-methods (Creswell 2003) evaluation inquiry. The study collected, analysed, and mixed both quantitative and qualitative data to evaluate the community-based teacher professional development programme of the Tanoto Foundation. The data in this study were collected through a survey, interviews, and observations. The survey was first completed and then interviews and observations were used as a follow-up to enlighten the quantitative results. The quantitative data provided broad information on teacher professional development (PD) from across all regions. On the other hand, the qualitative data provided a rich description of the teacher PD but for a smaller sample. Therefore, the study produced findings representative of the entire programme, enhanced with details from the qualitative data.

Concerning internal validity, this study triangulated the data through different research instruments. The participants' knowledge of student active learning, including their knowledge of what teachers and students should do assessed with questionnaires, and tests were analysed along with pre-observations interview with the participating teachers and principals. Following the quantitative data, the researchers investigated what they knew about active learning and classrooms practices through observation. Teachers were also asked their opinions on their teaching practice during the post-observation interviews. To verify what happened in the classroom, students were asked to answer questionnaires about the practice of active learning in the classroom.

As Alcoff (1991) warns about the danger of speaking for others and 'the possibility of misrepresentation, explaining one's own authority and privilege' (23), this study set out to take into account the different perspectives of the stakeholders (teachers, principals, and students) as described in Table 1.

Specifically, using the quantitative data, descriptive statistics were produced for each indicator related to the implementation of the teacher PD programmes for one academic year. The indicators are as follows: (1) the number of teachers trained in the AICEPL methods, (2) the contents of AICEPL training, (3) whether or not teachers and students can list AICEPL activities that occurred in their classroom, (4) teacher's self-perceived level of mastery with training materials, (5) number of PD activities, (6) frequency of teacher participation in PD

Table 1. Mapping of the stakeholders' perspectives.

\begin{tabular}{|c|c|c|}
\hline & Quantitative & Qualitative \\
\hline Perspectives & Knowledge & Classroom Practices \\
\hline \multirow[t]{4}{*}{ Teachers } & What did they think they know? & What did they think happened in class? \\
\hline & Survey (Tables 3, 4 and 5) & (Were learning outcomes achieved)? \\
\hline & What did they think they plan to do in class? & Post-Observation Interview (Table 6) \\
\hline & Pre-Observation Interview (in-text) & \\
\hline \multirow[t]{5}{*}{ Principals } & $\begin{array}{l}\text { What did they think their teachers know } \\
\text { about AICEPL? }\end{array}$ & \\
\hline & How did they think their teachers do in class? & \\
\hline & Interview (in-text) & \\
\hline & How did they know it? & \\
\hline & Survey (Table 7) & \\
\hline \multirow[t]{3}{*}{ Students } & & What did they see their teachers do in class? \\
\hline & & What did they think they do in class? \\
\hline & & Survey (Table 8) \\
\hline \multirow[t]{3}{*}{ Observers-Researchers } & & What did they see the teachers do in class? \\
\hline & & What did they see the students do in class? \\
\hline & & Observation (Tables 8 and 9) \\
\hline
\end{tabular}


activities, and (7) the number of PD activities involving other schools. All surveys were developed by the researchers for the purposes of this study's research questions. The teacher and student self-report surveys consisted of 38 and 42 items respectively. The principal survey contained 68 items. Included in the self-administered teacher survey were items querying their perceived mastery of student active learning (AICEPL) and to assess their knowledge of the topics covered in the PD sessions. For example, four questions asked them about student active learning, two questions dealt with the use of teaching-learning media, and two questions asked them to analyse two sample test items and choose which level of thinking each item referred to according to the modified Bloom's Taxonomy (Anderson and Krathwol 2001). The sample items were 'make a list of ten four-legged animals, categorise those ten animals into two, and state the reasons' and 'examine a picture of a polluted environment and draw a cleaner and healthier environment with the same elements of the first environment'.

Qualitative data were obtained through observation and interviews to reveal what they knew to improve their teaching practices. Therefore, teachers were observed by the research team in their classroom and given pre- and post- observation interviews. The classroom learning observation tool was comprised of 16 items. All observers were trained to use the structured observation instrument. The pre-observation interview was conducted to investigate teachers' knowledge of AICEPL and their teaching preparation while the post-observation interview aimed to verify whether they implemented their lesson planning and the reason for any discrepancy. According to Johnson and Turner (2003), observation and interviews - the kinds of data triangulation - enable researchers to find and collect relatively objective first-hand information. The interview data were then coded for key themes and used to support quantitative findings. The codes were generated from empirical data found during the school observations and from teachers' self report. These codes were then matched to major notions in the discourses of teaching-learning quality such as lesson-planning, students on task, group discussion, lecturing, and learner-centeredness to develop the key themes. The method of levels of analysis (Ary et al. 2010) were used to derive the key themes from the participants' voices expressed in the interview and in the self-report survey of which data were categorised through the RQDA software (Huang 2014).

All survey, observation, and interview instruments were piloted with principals, teachers, and students in similar schools in Indonesia. Instruments were then revised based on the pilot data (for further description see Tanoto Foundation 2016). The researchers had been involved in this study since the formulation of the research design, the development of the instruments, the piloting of the instruments, the trainings of the surveyors and classroom observers, the supervision of the data collection, and the data analysis. The data collection took a period of approximately four months from August through the first week of November 2015 (Figure 1).

The area of this study were eight districts in three programme provinces: Tanjung Jabung Barat and Tebo (Jambi Province); Asahan - Batubara, Labuan Batu, and Labuan Batu Selatan (North Sumatera); and Indragiri Hulu, Kuantan Sengingi and Pelalawan (Riau Province). The eight districts were selected based on consultation with the Tanoto Foundation considering the programme coverage and the variety of programme inputs. Within each district, eight elementary schools were selected based on a random procedure. In each school, three teachers who were teaching in the upper grade level classrooms (i.e. 4th to 6th grade) at the time of survey were selected, as these teachers were the target population of the training 


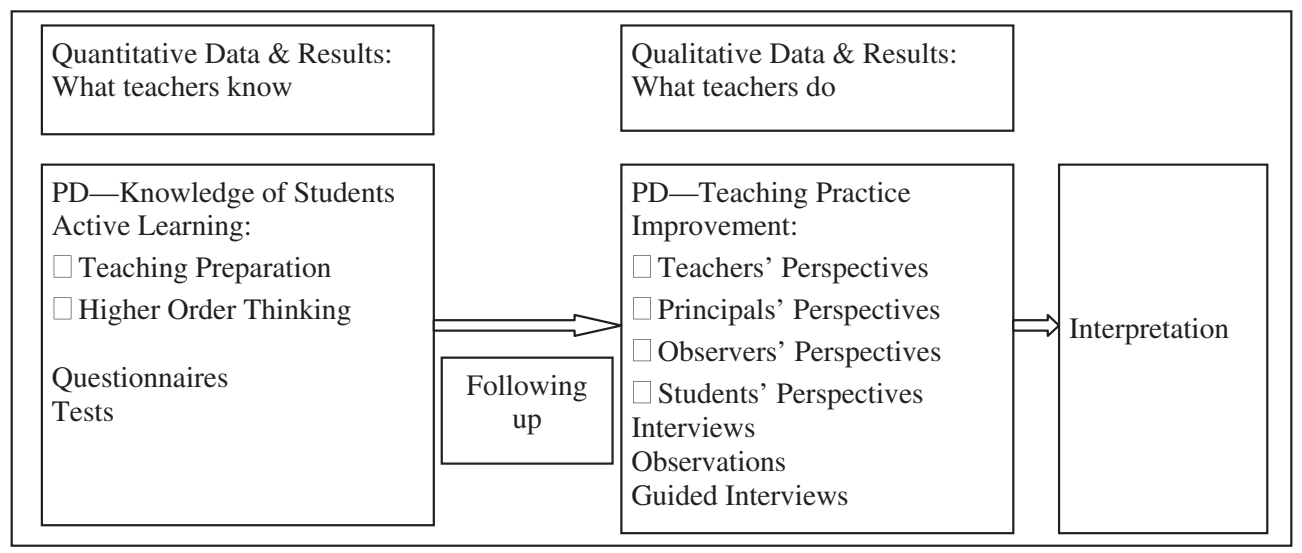

Figure 1. Research design.

programmes. The research team then interviewed the selected teachers prior to, and after, their teaching, observed their teaching and learning process in a one-hour lesson, and requested them to fill in the self-administered teacher survey. Between 15 and 20 students per observed classroom were randomly selected to participate in a student self-report survey. The total sample comprised 64 schools, 193 teachers, and 3457 students (see Table 2). Due to a forest fire during the data collection period, some sampled schools did not conduct any teaching activity and so several teachers' classroom teaching and learning could not be observed. Hence, there were only 177 teachers participating in the classroom observation.

The youngest age of the sampled teachers was 22, the oldest 57 and the median age was 38 (SD =9.3). Around $76 \%$ of these teachers have met the 2005 Teacher and Lecturer Law (that is they have graduated from at least a four-year college of education) while $24 \%$ of the sampled teachers have only a diploma from a three-year college and one did not answer

Table 2. School survey sampling design.

\begin{tabular}{|c|c|c|c|c|c|}
\hline \multirow[b]{2}{*}{ No } & \multirow{2}{*}{$\begin{array}{l}\text { Type of respond- } \\
\text { ents/informants/ } \\
\text { objects of obser- } \\
\text { vation }\end{array}$} & \multirow[b]{2}{*}{ Methods } & \multicolumn{2}{|c|}{$\begin{array}{c}\text { Numbers of respondents/ } \\
\text { informants/subjects-objects of } \\
\text { observation }\end{array}$} & \multirow[b]{2}{*}{ Remarks } \\
\hline & & & Plan & Realisation & \\
\hline 1. & School Principals & $\begin{array}{l}\text { Self-adminis- } \\
\text { tered survey }\end{array}$ & $\begin{array}{l}64 \text { school } \\
\text { principals }\end{array}$ & $\begin{array}{l}61 \text { school } \\
\text { principals }\end{array}$ & $\begin{array}{l}3 \text { principals were not } \\
\text { available during the } \\
\text { survey }\end{array}$ \\
\hline 2. & Teachers & $\begin{array}{l}\text { Self-adminis- } \\
\text { tered survey }\end{array}$ & $\begin{array}{l}3 \text { teachers } \times 64 \\
\text { schools }=192 \\
\text { teachers }\end{array}$ & 192 teachers & \\
\hline 3. & Teachers & Interview & 192 teachers & 193 teachers & $\begin{array}{l}\text { One case added was a } \\
\text { reserve case }\end{array}$ \\
\hline 4. & $\begin{array}{l}\text { Teachers' Class } \\
\text { Performance }\end{array}$ & $\begin{array}{l}\text { Interview \& } \\
\text { Observation }\end{array}$ & $\begin{array}{l}192 \text { class } \\
\text { sessions }\end{array}$ & 177 sessions & $\begin{array}{l}\text { Some schools were } \\
\text { temporarily closed } \\
\text { during survey due to } \\
\text { forest fire }\end{array}$ \\
\hline 5. & Students & $\begin{array}{l}\text { Guided } \\
\text { self-adminis- } \\
\text { tered survey }\end{array}$ & 3480 students & 3457 students & $\begin{array}{l}\text { Jambi }=881 \text { students } \\
\text { North Sumatera }=1418 \\
\text { students } \\
\text { Riau }=1158 \text { students }\end{array}$ \\
\hline
\end{tabular}


the question. This percentage of teachers who have met the required qualification is lower than that at the national level, i.e. $81 \%$ at the primary school level, $87 \%$ at the junior secondary school level, and $94 \%$ at the senior secondary school level (Badan Pusat Statistik 2016). This shortage of qualified teachers is one of the common shortcomings in remote areas as young qualified teachers are more attracted to teach in more developed regions. Most of those without the full degrees are those above 50, waiting for their retirement as those entering the teaching force after 2005 are required to have at least a four-year college degree in education. Since the areas of study are near plantations that have attracted workers from different regions, the teachers and students come from different ethnic and mother tongue backgrounds. Without support from non-governmental agencies, in-service education for teachers was rare because the local education authorities did not seem to place teacher professional development as a priority.

\section{Findings}

\section{Enhancement of knowledge of student active learning}

With regard to the first research question - to what extent the professional development sessions have enabled teachers to enhance their knowledge of student active learning, the results are presented in terms of two aspects that are required in student active learning: (a) sound preparation and planning, and (b) the teachers' knowledge of pedagogical content.

Writing a lesson plan is one of the main responsibilities of teachers. Correspondingly, $85 \%$ of the sampled teachers answered 'Yes' when asked whether they wrote lessons plans and implemented them effectively. Sixty seven (34\%) of those teachers reported having no issues in writing a lesson plan. These teachers were able to explain briefly about the topic, sub topic and learning outcomes. Fifty nine (30\%) teachers were able to write lesson plans and partially describe the topic, sub topic, and learning outcomes. Fifteen teachers (7.7\%) said that they were able to write lesson plans with only a few descriptions about the topic, sub topic or learning outcomes.

One open-ended question in the survey asked teachers to write activities they had put in their lesson plans. These self-reported activities were later compared with the observed teachers' and students' behaviours in class. The survey also investigated teachers' knowledge of pedagogical content. Three open-ended questions specifically refer to student active-learning; the first of these three questions asked what is active learning, the second one what they should do during active learning, and the last one what their students should do during active learning. Asked to write what they know about active learning, almost all teacher respondents (89\%) listed the names of the five modules covered in their professional development sessions: Developing Contextual Teaching and Learning, Higher Order Thinking, Problem Solving, Cooperative Learning, and Creating a Learning Environment that Motivates Students to Learn. Four teachers included the other two modules-Teaching Preparation and Practices and Action Planning whereas these two modules were the classroom practice and the follow-up plan after the five training sessions. Six teachers added Using Proper/Creative Media which was actually covered in the fifth module-Creating a Learning Environment that Motivates Students to Learn. Ten teachers gave varied answers ranging from 'complying with the curriculum' to 'relevant to students' needs'. Two teachers did not answer the question (see Table 3). 
For the last two questions, respondents could give more than one answer. Regarding what teachers should do during active learning, teacher respondents gave various answers. The three most frequent teacher activities as shown in Table 4 were guiding students (63\%), assigning students in groups (39\%), and checking students' work (28\%). In regard to what students should do, Table 5 shows that 139 of 192 teachers (or 72\%) mentioned asking questions, 91 of them (47\%) chose helping each other, and 82 teachers (43\%) thought working in their group as expected students' activities in student-active learning.

Contrary to the teachers' perceptions, the teachers' knowledge of pedagogical content was found to be incongruent. One indicator of success in any professional training is the participants' mastery of the training materials. Teachers' mastery of both the subject they are teaching and of the pedagogical content knowledge serves as a foundation to student performance. The results of the higher order thinking assessment included in the survey show that the sampled teachers selected a wide range of cognitive levels with high percentages of them reporting that these items referred to the lowest level of Remembering. In fact, only about $20 \%$ of the teachers indicated the correct cognitive levels of such items. The large percentage of teachers who could not answer correctly might suggest that these teachers had not yet fully absorbed the training content on higher order thinking. There still seems to be a gap between the purpose-content of the training materials and the teachers' pedagogical content knowledge. Thus, the self-perceived mastery of training materials was contradicted by the tested level of mastery with training materials.

\section{Improvement of teaching practices}

Information reported by teachers, principals, and students through interviews as well as classroom observation were used to answer the second research question, whether professional development sessions enable teachers to improve their teaching practices. Findings to answer this second research question are organised around the stakeholders' perspectives.

\section{Teachers' perspectives}

As teachers were trained to conduct learning-teaching activities applying student active-learning methods, they were expected to practice teaching with AICEPL. Indeed, the lesson plans should be implemented through the learning-teaching activities in the classroom. When asked whether they had planned for their lessons, what methods they were planning to use in their classes, and what learning outcomes they expected out of their

Table 4. Teachers' perspectives - what teachers should do in active learning.

\begin{tabular}{|c|c|c|c|}
\hline Key themes & Number & $\%$ of teachers & Description \\
\hline Guiding students & 121 & 63 & $\begin{array}{l}\text { Giving students instructions, explaining the lessons } \\
\text { and assignments }\end{array}$ \\
\hline Assigning students in groups & 75 & 39 & $\begin{array}{l}\text { Putting students into groups, giving instructions to } \\
\text { the groups, making sure the groups are on-task, } \\
\text { giving groups turn to work and present their work }\end{array}$ \\
\hline Checking students' work & 53 & 28 & $\begin{array}{l}\text { Moving around the classroom, making sure all } \\
\text { students are on task, answering students' questions, } \\
\text { correcting students' mistakes }\end{array}$ \\
\hline
\end{tabular}


Table 5. Teachers' perspectives - what students should do in active learning.

\begin{tabular}{lccl}
\hline Key themes & Number & \% of teachers & \multicolumn{1}{c}{ Description } \\
\hline Asking questions & 139 & 72 & Asking teachers or fellow students \\
Helping each other & 91 & 47 & Helping their team-mates \\
Working in their group & 82 & 43 & Working on the task in the group as assigned \\
\hline
\end{tabular}

teaching, our study found that teachers had started to apply only a few components of AICEPL but still tended to use more traditional direct teaching methods.

The pre-class observation interviews of the teachers revealed that the planned teaching techniques were mostly lecturing using questions and answers (44.91\%, 75 teachers), combination of questions and answers and other methods (43.11\%, 72 teachers), and combination of three teaching methods; lecturing, questions and answers, and another teaching method such as group discussion (12\%, 20 teachers). One teacher in SDN Lubuk Lawas, Jambi said,

Perlu memberikan penjelasan dan pengajaran dengan baik dan tuntas kepada para siswa sebelum bisa menugaskan mereka untuk melakukan kerja kelompok atau kegiatan lain. (Interview, 12 August 2015)

(It's necessary to give explanation and lecturing well and comprehensively to the students before I can assign them to do group work or other activities.)

The results of the interview were somewhat different from what teachers wrote in the survey as summarised in Table 4. Asked about what teachers should do in the survey, their responses (guiding students, assigning students in groups, and checking students' work) indicate their predisposition toward student active learning. Yet, when asked in the pre-observation interview what they planned to do, lecturing was still the most dominant teaching style and the expected learning outcomes were mostly lower order thinking - remembering and understanding. This could be due to the fact that the time of observation was still in the first few weeks of the new academic year after the one-month break. Therefore, teachers might not aim to achieve high cognitive levels in their planning of lessons so early in the year.

The post-classroom observation interviews found that the most teachers thought that they carried out their lesson plans well. About 112 (58\%) teachers stated that the learning objectives were achieved and the students understood the lessons taught in class completely. A smaller group of teachers $(n=42,22 \%)$ also claimed that the learning objectives were achieved with some reinforcements to understand the lessons better. A fifth-grade teacher in Labuhan Batu, North Sumatera mentioned that she'feels satisfied with the teaching and learning process. The learning objectives have been met well. Students understood the lesson well' (Interview, 24 September 2015).

Only a few teachers, specifically $6 \%(n=12)$, felt that the teaching objectives were not achieved. These teachers said that students had difficulties understanding the lessons and needed more assistance to grasp the whole concept. Table 6 summarises teachers' perceptions about the student attainment of the stated learning objectives after their class sessions.

However, although they claimed that they were able to write the learning outcomes according to Anderson and Krahtwohl's Taxonomy (2001), 38 teachers (20\%), formulated learning outcomes in a broader way than the ones covered in Anderson and Krahtwohl's 
Table 6. Teachers' view on how learning outcomes are achieved in class.

\begin{tabular}{lcc}
\hline Key themes & Number of teachers & \multicolumn{1}{c}{ Description } \\
\hline Learning outcomes are completed & 112 & $\begin{array}{c}\text { Students understand the lessons taught in } \\
\text { class completely } \\
\text { Students understand the lessons taught in } \\
\text { class but need more reinforcement to } \\
\text { Learning outcomes are partially completed } \\
\text { and reinforcement are needed by students }\end{array}$ \\
Learning outcomes are not completed & 42 & $\begin{array}{l}\text { Students find it difficult to understand the } \\
\text { lessons and need more assistance to grasp } \\
\text { the whole concept }\end{array}$ \\
\hline
\end{tabular}

Taxonomy. Instead of formulating learning outcomes, they mentioned vague and difficult-to-measure expectations for their students. For instance, these teachers mentioned that they expected their students to be smarter than themselves, wanted to help develop their students'future, or expected the students to be able to master the lesson. Fortunately, teachers still planned to allocate time for questions and answers and other teaching methods in their lesson plan so that students' participation - one of the aspects of AICEPL - was applied. Notwithstanding these findings, teachers seemed to be very confident about themselves and their mastery of active learning.

\section{Principal's perspectives}

Principals regarded their teachers pretty highly. None of them rated their teacher qualifications and effectiveness as poor. A total of 38(60\%) principals thought of their teacher effectiveness as good and 26 (40\%) as fair. Being responsible for teachers' tasks, the principals in this PD programme supervised their teachers in implementing the PD training materials directly and indirectly. Mostly they observed the teaching of the teachers in the classroom. Indirect observation was done through reports by the teachers themselves, the teachers' colleagues, and the students. Other forms of supervision methods were also carried out, but this was the least cited activity. As revealed in Table 7, most principals from the sampled schools ( $80 \%$ in North Sumatra and $81 \%$ in Jambi and Riau) indicated that they observed their own teachers through direct supervision for the implementation of the training materials.

Table 7. Methods for monitoring teacher implementation of training materials - principal self-report.

\begin{tabular}{|c|c|c|c|c|c|c|c|c|}
\hline & \multicolumn{2}{|c|}{ Jambi $(n=15)$} & \multicolumn{2}{|c|}{$\begin{array}{l}\text { North Sumatra } \\
\quad(n=21)\end{array}$} & \multicolumn{2}{|c|}{$\operatorname{Riau}(n=21)$} & \multicolumn{2}{|c|}{ Total $(n=57)$} \\
\hline & Yes & No & Yes & No & Yes & No & Yes & No \\
\hline $\begin{array}{l}\text { Report from } \\
\text { Teacher }\end{array}$ & $\begin{array}{c}40 \% \\
(n=6)\end{array}$ & $\begin{array}{c}60 \% \\
(n=9)\end{array}$ & $\begin{array}{c}19 \% \\
(n=4)\end{array}$ & $\begin{array}{c}81 \% \\
(n=17)\end{array}$ & $\begin{array}{c}19 \% \\
(n=4)\end{array}$ & $\begin{array}{c}81 \% \\
(n=17)\end{array}$ & $\begin{array}{c}25 \% \\
(n=14)\end{array}$ & $\begin{array}{c}75 \% \\
(n=43)\end{array}$ \\
\hline $\begin{array}{l}\text { Report from } \\
\text { other Teacher }\end{array}$ & $\begin{array}{c}20 \% \\
(n=3)\end{array}$ & $\begin{array}{c}80 \% \\
(n=12)\end{array}$ & $\begin{array}{l}10 \% \\
(n=2)\end{array}$ & $\begin{array}{c}90 \% \\
(n=19)\end{array}$ & $\begin{array}{c}10 \% \\
(n=2)\end{array}$ & $\begin{array}{c}90 \% \\
(n=19)\end{array}$ & $\begin{array}{c}12 \% \\
(n=7)\end{array}$ & $\begin{array}{c}88 \% \\
(n=50)\end{array}$ \\
\hline $\begin{array}{l}\text { Report from } \\
\text { Students }\end{array}$ & $\begin{array}{l}13 \% \\
(n=2)\end{array}$ & $\begin{array}{c}87 \% \\
(n=13)\end{array}$ & $5 \%(n=1)$ & $\begin{array}{c}95 \% \\
(n=20)\end{array}$ & $\begin{array}{c}5 \% \\
(n=1)\end{array}$ & $\begin{array}{c}95 \% \\
(n=20)\end{array}$ & $7 \%(n=4)$ & $\begin{array}{c}93 \% \\
(n=53)\end{array}$ \\
\hline $\begin{array}{l}\text { Direct } \\
\text { supervision or } \\
\text { observation }\end{array}$ & $\begin{array}{c}80 \% \\
(n=12)\end{array}$ & $\begin{array}{c}20 \% \\
(n=3)\end{array}$ & $\begin{array}{c}81 \% \\
(n=17)\end{array}$ & $\begin{array}{c}11 \% \\
(n=4)\end{array}$ & $\begin{array}{c}81 \% \\
(n=17)\end{array}$ & $\begin{array}{c}19 \% \\
(n=4)\end{array}$ & $\begin{array}{c}81 \% \\
(n=46)\end{array}$ & $\begin{array}{c}19 \% \\
(n=11)\end{array}$ \\
\hline Other Method & $\begin{array}{c}20 \% \\
(n=3)\end{array}$ & $\begin{array}{c}80 \% \\
(n=12)\end{array}$ & $5 \%(n=1)$ & $\begin{array}{c}95 \% \\
(n=20)\end{array}$ & $\begin{array}{c}5 \% \\
(n=1)\end{array}$ & $\begin{array}{c}95 \% \\
(n=18)\end{array}$ & $9 \%(n=5)$ & $\begin{array}{c}91 \% \\
(n=48)\end{array}$ \\
\hline $\begin{array}{l}\text { No Time to } \\
\text { Monitor }\end{array}$ & $0 \%(n=0)$ & $\begin{array}{c}100 \% \\
(n=15)\end{array}$ & $0 \%(n=0)$ & $\begin{array}{c}100 \% \\
(n=21)\end{array}$ & $\begin{array}{c}0 \% \\
(n=0)\end{array}$ & $\begin{array}{c}100 \% \\
(n=24)\end{array}$ & $0 \%(n=0)$ & $\begin{array}{c}100 \% \\
(n=57)\end{array}$ \\
\hline
\end{tabular}

Notes: Missing data for the item (Jambi $n=1$, North Sumatra $n=0$, Riau $n=3$ ) were not included in the listed percentages. 
The role of a school principal is important in ensuring that teachers implement what they have learned through the trainings. Principals of the sampled schools reported that they performed their supervisory task by visiting the classrooms fairly regularly. With regards to AICEPL, however, this finding is not consistent with the other findings on the teaching and learning processes in the classrooms. This implies two possibilities. The school principals may not have grasped the concepts of AICEPL; therefore, they were not able to identify what needed to be improved in teaching practices in their schools. The other possibility is that the school principals may not have used proper and effective methods of supervision. According to Cramer (1999) some principals may not have time to plan and deal with theoretical problems (such as those of AICEPL); indeed, they may not have time to discuss even practical topics such as classroom strategies with the teachers. Principals must plan programmes of supervision of instruction well to ensure that teachers deliver the lesson according to the applied teaching approach.

\section{Observers' and students' perspectives}

To investigate how the PD trainings have enabled teachers to improve their teaching practices, specifically the engagement of Student Active Learning, our study set out a list of observable teacher behaviours such as talking in front of class, writing on the board, asking questions, walking around the classroom and student behaviours such as asking questions, working in small groups, copying from the board. This list was synthesised from the recommended activities contained in the training modules and used as the basis for classroom observations by trained observers. To address the research question on teaching practices improvement, observers recorded ratings during the teacher's classroom teaching practice.

It should be noted that while observers reported on observing a one-hour lesson, students reported about their learning experience over the course of the school year in the guided interviews. The classroom observations revealed consistent findings with those in the students' survey but which differ from the teachers' self-administered surveys. In general, teachers believed that their students demonstrated more initiative (i.e. by asking questions) than was observed by the observers and reported by the students themselves. What the teachers perceived about their students seemed to differ from what actually happened in class during observation and from what students reported: When observed during their class session, teachers demonstrated more teacher-centred approaches, and correspondingly, students also reported more teacher-centred behaviours. Table 8 displays the teachers' three most dominant behaviours observed during a 50-min classroom observation and the three most common ones reported by students. Although the categories themselves are somewhat different, the observers and students agree on the teacher-centredness in the classrooms.

Table 9 reveals what was found when the observers turned their attention to student behaviours in the classrooms. More than half of the observed teachers ( $n=101,57 \%)$ were seen to have failed to engage their students actively in the teaching and learning process.

Table 8. Teachers' three most dominant behaviours as observed by surveyor and reported by students.

\begin{tabular}{llll}
\hline Surveyors & \multicolumn{2}{c}{ Students } \\
\hline Talking and explaining the lesson & $91 \%$ & Writing on the board & $68 \%$ \\
Standing in front of the classroom & $86 \%$ & Talking and explaining the lesson & $66 \%$ \\
Writing on the board & $71 \%$ & Checking students' work at his/her desks & $35 \%$ \\
\hline
\end{tabular}


Table 9. Student behaviours in class - observed.

\begin{tabular}{|c|c|c|}
\hline Key Themes & Number & Description \\
\hline Students are passive & 101 & $\begin{array}{l}\text { Students are not actively engaged in the teaching and learning } \\
\text { process }\end{array}$ \\
\hline Students are either active or passive & 23 & $\begin{array}{l}\text { Students are not engaged fully in class activities during teaching } \\
\text { and learning process }\end{array}$ \\
\hline Students are active & 53 & $\begin{array}{l}\text { Students are fully engaged in class activities during the teaching } \\
\text { and learning process }\end{array}$ \\
\hline
\end{tabular}

The next largest group, 53 teachers (30\%), managed to engage their students actively in the learning activities. In-between, 23 teachers (13\%) were observed to have attempted to invoke student active learning but have not managed to facilitate student-initiated active learning and achieve their full engagement. Thus, although the teachers tend to think they are engaging the students actively, the observers and students themselves disagree with the teachers on this crucial outcome.

Despite the findings on the need for improvement in teachers' knowledge and practices, it is noteworthy that students showed very positive attitudes about their classroom experiences and valued their teachers highly. Almost all students across the three provinces (99\% in North Sumatra and Jambi, and $98 \%$ in Riau) reported that they were happy, and that they enjoyed their learning and were in high spirits when asked about their feelings in the classroom on the day of the survey. When a group of students in SDN 156, Lubuk Lawas, Jambi, were asked how they felt about their school and class, one student volunteered and said 'Senang. Suka belajar di sini. Ibu guru baik' (Happy. Love learning here. The teacher is good). This student was then cheered by her schoolmates (SDN 156, Lubuk Lawas, Jambi, 12 August 2017).

When asked to rate their own teacher, less than $10 \%$ of the students found their teachers less than great. These findings are consistent with those in the PISA (Gurría 2012) study which revealed that $96 \%$ of students in Indonesia reported being happy in school. This phenomenon should be interpreted in light of the possibility that these high and positive ratings of students' attitudes may be culturally-bound.

\section{Discussion}

The results show that teachers' knowledge of student active learning is in need of improvement, particularly in the areas of encouraging higher-order thinking skills and student-centred learning. These findings are consistent with results of other studies on student teachers' experiences. There is a gap between theoretical and practical knowledge as soon as student teachers enter the real classroom setting (Cheng, Cheng, and Tang 2010). This is because of their misinterpretation of the theory or its faulty implementation, or their own inconsistencies. This may also occur if the pre-training experiences or teaching context influences have a stronger impact on the teachers than the current professional development programme.

The seeming gap between the teachers' theoretical and practical knowledge may also be due to the possibility that teachers are still striving to make sense of the lessons gained from their PD trainings and incorporate the new ideas into their practical knowledge. Another possibility is also the researchers' constraints of location as teacher educators who are yet 
to understand teachers in their professional practices in remote areas with inadequate resources. In this study, the researchers do not presume to, as Alcoff (1991) warns, 'speak for others' but only attempt to'speak about others'. Furthermore, this speaking about the teachers in this study was done not with the intention of judging how well those teachers had done, but with the empathetic spirit of how the PD programme had benefitted those teachers and with the constructive act of what could be improved in the programme to benefit them even more.

As the teachers themselves reported, teachers seemed to have attempted applying active learning principles in their classrooms by engaging their students in group-work. This was confirmed by the classroom observation and their students' opinions. The most dominant student behaviours already revealed promising indications of active learning as shown by asking questions and working in groups. However, the dominant learning processes in the classrooms still tended to be teacher-directed rather than student-initiated. The three most common teacher activities in class are lecturing, standing in front of the classroom, and writing on the board. Thus, the teachers' capacity to facilitate more student-initiated activities needs to be further enhanced. Cooperative learning and active learning activities as taught in the professional development sessions should be integrated further into their classroom practices.

The students' positive attitude is noteworthy. They valued their classroom experiences and their teachers highly. The high and positive ratings of students' attitudes may be culturally-based. 'Total obedience, unquestioning mind, and the belief ... that the teacher can do no wrong normally portray the learning atmosphere in many classrooms' (Marcellino 2008, 58). Such classes rarely criticise teachers but respect their teaching. Indonesian students particularly those in remote areas, do not normally have demanding expectations for their teachers, their learning experiences, and the school's resources. This situation is related to the value of peace loving which instructs students to have 'attitudes, speech, and actions that cause other people to feel happy and secure due to one's presence' as prescribed by the MoEC (Kemendiknas 2010). Students in rural areas also tend to be more appreciative and respectful of their teachers than their counterparts in big cities. Thus, the students' positive attitude towards their teachers and learning experiences should not be interpreted as an indicator of teaching effectiveness and may not always be associated with enhanced learning outcomes. This cultural context, however, may be a very conducive environment for learning and performing if teachers can be encouraged further to apply what they have been trained. The students' positive attitude can be a starting point for active learning to happen and to achieve higher learning outcomes.

\section{Implications}

The Tanoto Foundation is engaged in teacher upgrading projects to improve the quality of education in Indonesia. The areas of teacher development where private enterprises can help support the government (as presented in Figure 2) include continuous professional development for in-service teachers and teacher performance appraisal. These areas complement the initial formation of pre-service teachers in teacher education programmes and the certification programme, which are the sole responsibility of the government. Public participation in community-based professional development for teachers needs to be instrumental and complementary to the planned policy by the MoEC to conduct teacher 


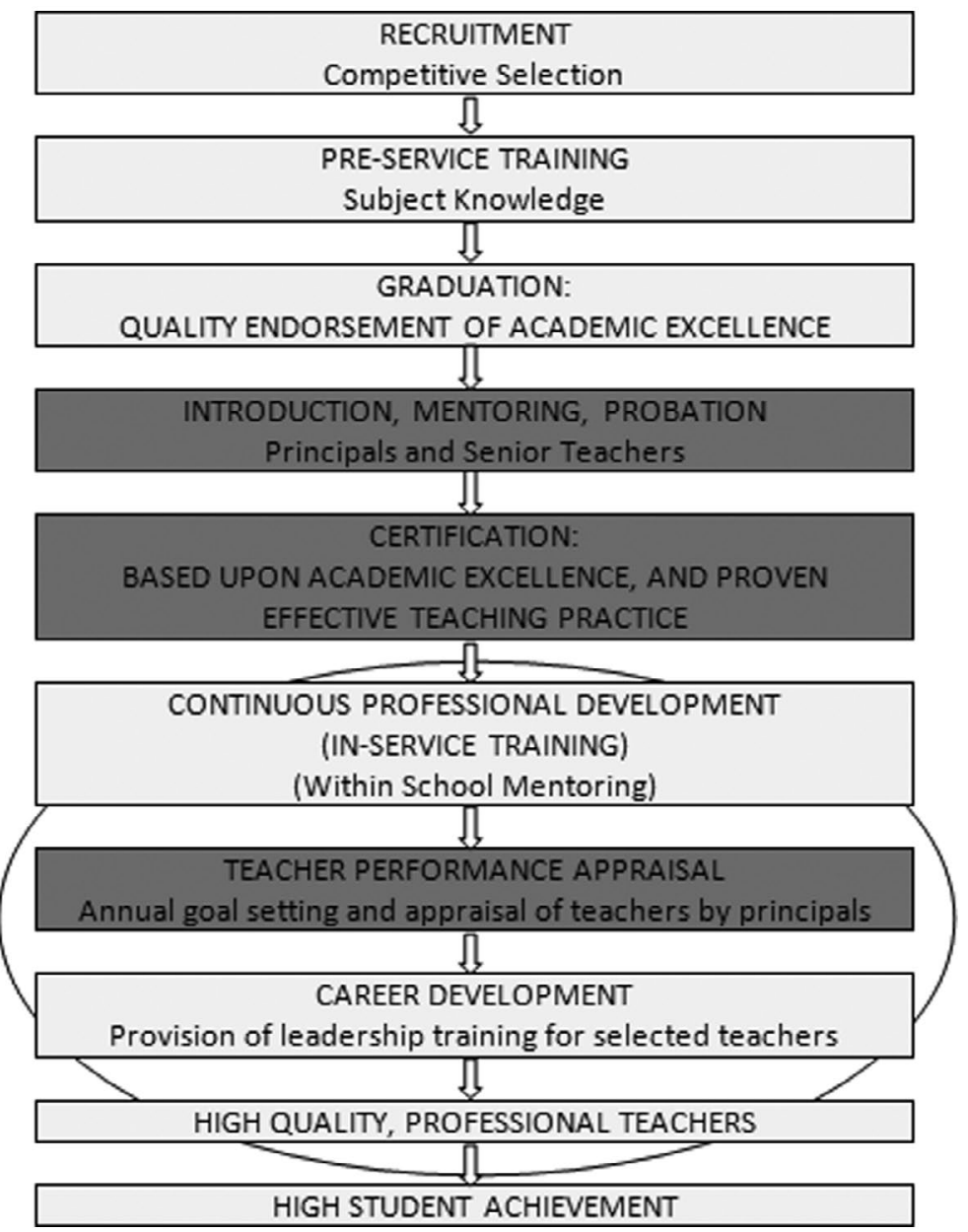

Figure 2. Framework for the development of the quality of teachers. Source: Impact of certification on teacher quality, World Bank (2013).

performance appraisal and link the scheme with salary increments towards a system of remuneration and promotion based on merit.

Nevertheless, educators in remote areas should attempt to reduce the schools' dependence on external resources. In line with Rass' study (2012) reporting that 'the mentor and the inductee should teach at the same school' (157), the PD programmes should eventually be organised and facilitated internally within the school district. When local education authorities have difficulties in providing PD programme, educators should generate local facilitators to share their best classroom practices and serve as peer models for other teachers. One of the merits of the Tanoto Foundation PD programme is that the training has managed to empower teachers to be local facilitators through the professional development sessions among schools. The availability of local facilitators was one of the requirements of the formation of professional learning circles and is crucial to the sustainability of any strategy or programme to improve the quality of schools, especially in remote areas. The programme 
also selected potential local facilitators among the participating teachers and conducted Training of Trainers for them.

\section{Limitations}

The limitations of this study include the lack of in-depth analysis of each teacher's perspectives, the deductive stance, and the triangulation issues. First, given the nature of the study and the number of teacher participants, the research team had to make choices of presenting the overall descriptive data of all the respondents or taking a specific slice of the perspectives and exploring the voices in a greater depth. As this present study aimed to investigate to what extent the PD programme enable the participating teachers overall to enhance their knowledge and improve their teaching practices, the latter leaves room for further research on the narrative voices of participants.

Second, in formulating the questions in the survey and interview, the research team may have been exercising the power with our access to the literature on teacher professional development and student learning while lying on our ignorance of the reality of teachers' lives and classroom practices, particularly in the context of remote areas. The list of teacher and student behaviours used in the observation instrument particularly may have been imposed on the teachers' teaching practices based on the researchers' knowledge and the information from the PD modules. As there is a gap between theoretical and practical knowledge within teachers, likewise there may also be a gap between the researchers' knowledge and the teachers' reality and perspectives. To reduce the researchers' biases and to safeguard this 'speaking about these teachers' (Alcoff 1991) as congruent as possible to the teachers' classroom reality, the method of data collection has been varied to include all the different perspectives of the different stakeholders through different ways-survey, interviews, and observation as summarised in Table 1.

Finally, different triangulation data could usually be found in qualitative research. Teachers' perspectives on active learning were different from what happened in the classroom as seen by observers and students. Although observation data could substantiate the findings (Merriam 1998), Nation (1997) asserts that observation data represents behaviour rather than the behaviour itself. As argued by Johnson and Turner (2003), further study was suggested to combine observation and further interviews to explore teachers' explanation for the differences between their perspectives and the observers' and students' perceptions.

\section{Conclusion}

Improving teacher quality in Indonesia is one of the objectives of the Tanoto Foundation's SIP. The results of the study give insights to further improve teacher PD with special emphasis on enhanced knowledge and improved teaching practices, especially in the areas of higher-order thinking skills and student-centred learning. Further PD programmes conducted by the government or the Tanoto Foundation's SIP should not be limited to sessions of trainings but also to principals' or mentors' supervisions in the real classrooms. Indeed, further PD should consider students' positive attitude towards teachers and their teaching contextually and critically. 


\section{Acknowledgements}

This evaluation study was made possible through a grant from the Tanoto Foundation. The authors wish to thank Sihol Aritonang, Ari Widowati, Rahmat Setiawan and the Tanoto Foundation support team as well as the surveyors team led by Frieda Subrata and Risang Rimbatmaja.

\section{Disclosure statement}

No potential conflict of interest was reported by the authors.

\section{Funding}

This work was supported by the Tanoto Foundation.

\section{ORCID}

Ignatius Harjanto (iD http://orcid.org/0000-0001-8914-6142

Anita Lie (iD) http://orcid.org/0000-0003-4818-2811

Diah Wihardini (D) http://orcid.org/0000-0002-0680-0426

Laura Pryor (iD) http://orcid.org/0000-0002-0958-6584

Mark Wilson (iD http://orcid.org/0000-0002-0425-5305

\section{References}

Abbas, H. 2013. "Inconvenient Truths about Teacher Certification Program." The Jakarta Post, April 27. Alcoff, L. 1991. "The Problem of Speaking for Others." Cultural Critique 1991-1992 (Winter): 5-32.

Anderson, L. W., and D. R. Krathwol. 2001. A Taxonomy for Learning, Teaching, and Assessing: A Revision of Bloom's Taxonomy of Education Objectives. New York: Addison Wesley Longman.

Archibald, S., J. G. Coggshall, A. Croft, and L. Goe. 2011. "High-quality Professional Development for All Teachers: Effectively Allocating Resources." National Comprehensive Centre for Teacher Quality. Accessed September 4, 2016. http://www.gtlcentre.org/sites/default/files/docs/ HighQualityProfessionalDevelopment.pdf

Ary, D., L. C. Jacobs, A. Razavieh, and C. K. Sorensen. 2010. Introduction to Research in Education. Wadsworth, $\mathrm{OH}$ : Cengage Learning.

Badan Pusat Statistik. 2016. Potret pendidikan Indonesia:statistik pendidikan 2016 [Profile of Indonesian Education: Education Statistics 2016]. Jakarta: Badan Pusat Statistik.

Bai, B. 2014. “Enhancing In-service Teachers' Professional Learning through a School-based Professional Development Programme in Hong Kong." Journal of Education for Teaching 40 (4): 434-436. doi:10.1080/02607476.2014.929380. Accessed April 22, 2016. http://www.tandfonline.com/action/ journallnformation?journalCode $=$ cjet20

Barber, M., and M. Mourshed. 2007. How the World's Best Performing Schools Come out on Top. London: McKinsey and Company.

Blank, R. K., and N. de las Alas. 2009. Effects of Teacher Professional Development on Gains in Student Achievement. Washington, DC: CCSSO.

Chang, M. C., S. Shaeffer, S. Al-Samarrai, A. B. Ragatz, J. de Ree, and R. Stevenson. 2014. Teacher Reform in Indonesia: The Role of Politics and Evidence in Policy Making. Washington, DC: World Bank.

Cheng, M. M. H., A. Y. N. Cheng, and S. Y. F. Tang. 2010. "Closing the Gap between the Theory and Practice of Teaching: Implications for Teacher Education Programmes in Hong Kong." Journal of Education for Teaching. 36, no. 1 (Feb.): 91-104. Accessed September 6, 2016. http://www.tandfonline.com/ loi/cjet20 
Chetty, Raj, J. N. Friedman, and J. E. Rockoff. 2011. The Long-Term Impacts of Teachers: Teacher Valueadded and Student Outcomes in Adulthood. Working paper No. 17699. National Bureau of Economic Research. Accessed September 1, 2016. http://www.nber.org/papers/w17699.pdf

Cramer, R. V. 1999. Administration and Supervision in the Elementary School. New York, NY: Harper and Brothers.

Creswell, J. W. 2003. Research Design: Qualitative, Quantitative, and Mixed Methods Approaches. London: SAGE Publications.

Czerniawski, G. 2013. "Professional Development for Professional Learners: Teachers' Experiences in Norway, Germany and England." Journal of Education for Teaching 39 (4): 383-399. Accessed September 6, 2016. doi:10.1080/02607476.2013.769339

Darling-Hammond, L. 2000a. “How Teacher Education Matters." Journal of Teacher Education 51 (3): 166173. Accessed September 11, 2016. http://wiki.sugarlabs.org/images/a/aa/Darling_Hammond.pdf

Darling-Hammond, L. 2000b. "Teacher Quality and Student Achievement: A Review of State Policy Evidence." Education Policy Analysis Archives 8 (1): 1-44. Accessed September 11, 2016. http://files. eric.ed.gov/fulltext/EJ853513.pdf

Darling-Hammond, L., and B. Berry. 2006. "Highly Qualified Teachers for All." Educational Leadership 64 (3). Accessed September 11, 2016 http://www.csun.edu/ krowlands/Content/SED610/NCLB/ NCLB\%20from\%202007/highly\%20qualified\%20teachers.pdf

Díaz-Maggioli, G. 2004. Teacher-centred Professional Development. Alexandria: ASCD.

Ebersöhn, L., T. Loots, I. Eloff, and R. Ferreira. 2015. In-service Teacher Training to Provide Psychosocial Support and Care in High-risk and High-need Schools: School-based Intervention Partnerships. doi:1 0.1080/02607476.2015.1044226. Accessed August 26, 2016. http://www.tandfonline.com/action/ journallnformation?journalCode $=$ cjet20

Evans, D., S. Tate, R. Navarro, and M. Nicolls. 2009. Teacher Education and Professional Development in Indonesia. A Gap Analysis. USAID document. Accessed September 8, 2016. http://pdf.usaid.gov/ pdf_docs/PNADS282.pdf

Fahmi, M., A. Maulana, and A. A. Yusuf. 2011. Teacher Certification in Indonesia: A Confusion between Means and Ends. Bandung: Padjajaran University.

Gurría, A. 2012. PISA 2012 Results in Focus: What 15-Year-Olds Know and What They Can Do with What They Know. Accessed September 8, 2016. https://www.oecd.org/pisa/keyfindings/pisa-2012-resultsoverview.pdf

Howe, E. R. 2014. "A Narrative of Teacher Education in Canada: Multiculturalism, Technology, Bridging Theory and Practice." Journal of Education for Teaching 40 (5): 588-599. doi:10.1080/02607476.2014 .956540. Accessed September 6, 2016. http://www.tandfonline.com/loi/cjet20

Huang, R. 2014. RQDA:R-based Qualitative Data Analysis. R Package Version 0.2-7. http://rqda.r-forge.rproject.org/.

Jalal, F., M. Samani, M. C. Chang, R. Stevenson, A. B. Ragatz, and S. D. Negara. 2009. Teacher Certification in Indonesia: A Strategy for Teacher Quality Improvement. Jakarta: Ministry of National Education and World Bank Staff and Consultants.

Johnson, B., and L. A.Turner. 2003. "Data Collection Strategies in Mixed Methods Research."In Handbook of Mixed Methods in Social and Behavioral Research, edited by A. Tashakkori and C. Teddie, 297-319. Thousand Oaks, CA: Sage.

Kementerian Pendidikan Nasional (Kemendiknas), Badan penilitian dan pengembangan pusat kurikulum. 2010. Pengembangan Pendidikan Budaya Dan Karakter Bangsa Pedoman Sekolah. Accessed June 5, 2016. http://gurupembaharu.com/home/wp-content/uploads/downloads/2011/11/ Panduan-Penerapan-Pendidikan-Karakter-Bangsa.pdf

Kingdon, G.G. 2006. Teacher Characteristics and Student Performance in India: A Pupil Fixed Effects Approach. Global Poverty Research Group Working Paper 59. Accessed September 8, 2016. http:// economics.ouls.ox.ac.uk/14026/1/gprg-wps-059.pdf

Koning, M. 2012. Reforming Teacher Education in Indonesia: Are They Taking the Quality out of Education? Accessed June 10, 2016. http://worldsofeducation.org/en/magazines/articles/118

Marcellino, M. 2008. “English Language Teaching in Indonesia: A Continuous Challenge in Education and Cultural Diversity". TEFLIN Journal 19, no. 1 (Feb.): 57-69. 
Merriam, S. B. 1998. Qualitative Research and Case Study Applications in Education. San Francisco, CA: Jossey-Bass.

Nation, J. R. 1997. Research Methods. Upper Saddle River, NJ: Prentice Hall.

Rass, R. A. 2012. "Supporting Newly Recruited Teachers in a Unique Area, the Northwest Territories in Canada." Journal of Education for Teaching 38, no. 2 (Apr.): 141-161. Accessed December 6, 2016. http://www.tandfonline.com/loi/cjet20

Rice, J. K. 2003. Teacher Quality: Understanding the Effectiveness of Teacher Attributes. Washington, DC: Economic Policy Institute.

Schleicher, A. 2015. Education in Indonesia: Rising to the Challenge. Paris: OECD Publishing / OECD/Asian Development Bank. Accessed April 10, 2016. doi:10.1787/9789264230750-en.

Shi, X., and P. A. J. Englert. 2010. "Reform of Teacher Education in China." Journal of Education for Teaching 34, no. 4 (Nov.): 347-359. Accessed September 6, 2016. http://www.tandfonline.com/ action/journallnformation?journalCode=cjet20

Tanoto Foundation. 2016. Taking Part in Educating Our Children: An Evaluation Study of Pelita Pendidikan Program. Jakarta: Graduate School Widya Mandala Catholic University and BEAR Centre UC Berkeley.

Tayyaba, S. 2012. "Rural-Urban Gaps in Academic Achievement, Schooling Conditions, Student, and Teachers' Characteristics in Pakistan." International Journal of Educational Management 26 (1): 6-26.

Tirri, K. 2014. "The Last 40 Years in Finnish Teacher Education." Journal of Education for Teaching 40 (5): 600-609. Accessed September 6, 2016. http://www.tandfonline.com/action/ journallnformation?journalCode $=$ cjet20

Walter, C., and J. Briggs. 2012. What Professional Development Makes the Most Difference to Teachers? A report sponsored by Oxford University Press. Accessed August 22, 2016. http://www.education. ox.ac.uk/wordpress/wp-content/uploads/2010/07/WalterBriggs_2012_TeacherDevelopment_ public_v2.pdf

Wang, Q., and Z. Lu. 2012. "A Case Study of Using an Online Community of Practice for Teachers' Professional Development at a Secondary School in China." Learning, Media and Technology 37 (4): 429-446.

World Bank. 2010. Transforming Indonesia's Teaching Forces. Vol. 1. Human Development East Asia and Pacific Region Report No. 53732-ID. Jakarta: World Bank Office.

World Bank. 2013. Impact of Teacher Qualification on Teacher Quality. Jakarta: World Bank Office. 